\title{
Identifying the Effect of Entrepreneurship Approach on the Banking Industry Development Strategy (Study at Bank Mellat)
}

\author{
Mahboobeh Zohari ${ }^{1}$, Reza MohammadKazemi ${ }^{2}$ \\ ${ }^{1}$ Master of Management in Entrepreneurship, Faculty of Entrepreneurship, University of Tehran, Iran \\ ${ }^{2}$ Associate Professor \& Head of New Business Creation Department, Faculty of Entrepreneurship, University of \\ Tehran, Iran
}

Correspondence: Mahboobeh Zohari, Master of Management in Entrepreneurship, Faculty of Entrepreneurship, University of Tehran, Iran

Received: November 4, 2016

Accepted: April 6, 2017

Online Published: May 24, 2017

doi:10.5539/ibr.v10n6p236

URL: https://doi.org/10.5539/ibr.v10n6p236

\begin{abstract}
Approach to entrepreneurship and strategy of development is the concepts that have attracted the attention of many researchers and managers from the theoretical and practical dimension, and many companies have used these two concepts, and have won a lot of success. In today's world, the entrepreneurship is known as an engine of local, regional and national economic development. (Ahmadpour, 2007) The process of economic development in developed countries reflects the fact that the economy is under the influence of entrepreneurship. In addition, in the current competitive environment, it is an important factor in the development and survi val of the companies. Companies that put the entrepreneurial orientation as their policy approach, through the development of flexible resources, they can increase their long-term potential. (Khanka, 2003) Therefore, in this paper, we examine the relationship between development strategy and entrepreneurship dimensions, including innovation, risk-taking, activism, and competitive aggression in the Mellat bank. The research is applied and is done in correlation way. The questionnaire is used to collect data. The statistical population of the study was limited that 261 statistical samples were used in the analysis. The research findings show that entrepreneurship approaches have a strong and positive impact on its development strategy. The Moderating Competitive dynamic has no impact on the relationship between entrepreneurship approach and development strategy. The findings of this study will help decision-makers to be able to know the importance of entrepreneurial approach so that they can decide appropriate policies to create and launch apps. Based on the results obtained, recommendations are provided for statistical population and bank managers.
\end{abstract}

Keywords: entrepreneurship, strategy of development, risk, competitive aggression, Bank Mellat

\section{Introduction}

Today, an entrepreneur is called as the engine of economic development (Mcgrath \& Macmillan, 2000). Entrepreneurship because the community has led to ingenious technical change and economic growth growth is causing and as well as entrepreneurial new knowledge into new products and services will become important. (Salazar, 2004) also believes that entrepreneurs in addition to creating jobs, increasing quality of life, income distribution, social anxiety reduction and utilization of national resources. In addition, one of the biggest challenges for different societies is the issue of rapidly and growing changes that, every year, but every day, we are witnessing more than ever, in all sectors of human society, ranging from cultural, political and economic. Analysis of several developed and de veloping countries, which have followed their path to success, has shown that one of the most important factors in the development of these countries are strengthening the private sector. In particular, the presence of small and independent businesses and entrepreneurial organizations, as dynamic and creative organization that coordinate their strategy, structure and performance quickly with the modern developments. (AhmadPour Dariyani, M., \& Moghimi, M. 2006)

Today, unlike in the past, the global markets are facing with daily changes and even moment-to-moment needs of human societies and manufacturing and services organizations that are the main cause for meeting these needs, should move quickly and with the correct target to not being stay behind of rapid changes, survival and growth 
in this market. In fact, for today's organizations, creativity, inno vation and entrepreneurship, either are as steps of a ladder, which must be passed with full awareness and successfully (Farhangi \& Safarzadeh, 2007). The main aim of Entrepreneurs (in the public and private sectors) is creating the ability to cope with changes for the betterment of society (Lynch, 2006).

Entrepreneurial firms are better off entering a select number ofstrategic alliances and focusing on enhancing the outcomes of those select alliances as well as developing a dynamic alliance management capability. Such firms benefit most from establishing a moderate number of alliances rather than depending on a small number of alliances or becoming overwhelmed with a great number of alliances.

\section{Copyright @ 2016 Strategic Management Society}

The privatization of entities, especially financial institutions, increased competition, competitive advantage, information technology and electronic banking have caused the designed structure does not respond the new needs and forces the banking industry to develop its activities in the field of increasing the variety of services and products, creation of investment business and the related business. Meanwhile, the need for entrepreneurial activities in the banking system is more crucial than ever.

Using existing resources, even in a critical condition of the economy, we should also make appropriate decisions, identify opportunities, invent, innovate, create new products, create businesses, and take steps to provide new jobs. Identifying entrepreneurship in the banking industry does not only make progress and the development of banking, but also it creates and grows small economic businesses and new economic activities that will entail the following results:

The creation of wealth in society, production of technology, proper jobs, especially for young people.

This study aims to study the concept of entrepreneurial orientation provided by (Lumpkin \& Veds, 1996). For this purpose, after reviewing prior studies and approaches, it studied the developing entrepreneurship approach and strategy, and then it offers a model to measure.

\section{A review of the Research Literature}

Every concept has a specific vision and approaches and the concept of entrepreneurship is not an exception. From the perspective of entrepreneurs, entrepreneurs are a style of management. The objective of entrepreneurial management is strategic management that organizes and examines all the items. Entrepreneurship is an approach to management that could be learned (Wickham, 2000).

Special attention to entrepreneurs in organizations is mainly due to keep the employees and their thoughts active in the organization and rehabilitation in the hierarchical structure of the organization (Pardakhtchi and Shafi'zadeh, 2005). To increase performance in both ways of strategic modernization and new venture opportunities, organizations have engaged themselves in entrepreneurship. (Guth and Ginsberg, 1990; Stevenson and Jarillo, 1990)

Exploration, evaluation and extraction of opportunity are a defining feature of entrepreneurship (Shane, 2003; Shane and Venkataraman, 2000) and the amount that organizations operate entrepreneurial is in relation to their ability to produce new products and services. (Lumpkin and Dess, 1997) According to Artokol, entrepreneurship is purposeful activity, which consists of a series of coherent decisions for individual or group of people to create, develop or maintain economic unit. On the other hand, "Robert Neshtat" has considered the entrepreneurial culture to accept the risk, pursue opportunities, and satisfy the needs, through inno vation and the es tablishment of a business and labor. (Ahmadpour Daryani, 2008)

The ineffectiveness of traditional methods of management, intense competition between organizations and small business growth would cause the serious attention of organizations to innovation; because they have considered the innovation the only guarantee of survival in the field of competition. Therefore, they have tried to encourage the creative people and entrepreneurs that were the main producer of new products and services in the organization, to remain in the organizations and their ideas in the Pinkat organization and called these people corporate entrepreneurship (Gholipour and et al., 2008: 166).

A feature of entrepreneurial organization is having the clear, continuous, customer-oriented and flexible mission so that encourage the organization's growth through new ventures. In fact, one of the most important factors in the development of organizational entrepreneurship is that all staffs understand the mission of the organization and work towards its realization (Hadizadeh and Rahim Fil Abadi, 2005).

Accordingly, organizational strategy should be entrepreneurial strategies. For example, Scholhommer considers the entrepreneurship strategy consists of a series of targeted activities that act in order to equip and use of 
resources. The strategies that this authority has proposed to include administrative entrepreneurship, opportunity-oriented entrepreneurs, imitation entrepreneurship, acquired entrepreneurship and educational entrepreneurship.

In recent years, the banking industry has witnessed intense competition combined with many opportunities and threats. Certainly, no bank can provide all possible services and be the best in the services it offers. Banks can evaluate their strengths and opportunities in the market, to adopt strategies and to achieve a good competitive position in the market. (Kermanshah and Abdi, 2006)

Research shows that various factors, such as the organization's external environment, the strategy of the organization and management practices are effective factors in organizational entrepreneurship (Koartko et al, 1990). In a number of studies, it has been trying to expand the conceptual model, and classify the factors affecting the development of organizational entrepreneurship. Lumpkin and Dess (1996) have considered four key factors, including entrepreneurial orientation, organizational factors, environmental factors and organizational performance for entrepreneurship.

Banks as economic firms, according to the country's future prospects, with a move towards privatization and competitive conditions, it is necessary to train managers that in addition to the ability and management skills, use the creativity, innovation and risk taking of their entrepreneurial attitude, in order to achieve their own purposes (Divandari, Hassanpour, 2007).

Renowned management theorists and managers have considered the innovation, as something more than an issue of interest. In their opinion, innovation has a vital role in providing and maintaining a competitive advantage in the bank, for example, leading banks are seeking to maintain their distance relative to their competitors. These banks provide new services at different times to the market (Porter, 1980).

The Mellat Bank has sought to implement Article 44 of the Constitution of the Islamic Republic of Iran, and has joined the private banks and has considered an approach to entrepreneurship in its product and service development strategy to improve the share of resources and customers. It considers creating value with considering entrepreneurship, innovation, improvement, change and diversity in service delivery and increase production for its customers. Now the question is whether entrepreneurial approaches are effective on the development strategy of Bank Mellat in Tehran.

Despite the importance of the discussion above, in the banking system, so far, there was less research in the field of entrepreneurial approaches in the banking industry. Therefore, this study aims to identify the entrepreneurial approaches in Bank Mellat, and determine its effects on Development Strategies. In addition, it can be concluded that in case of doing the stages and reaching all the major and minor goals, this research may be considered innovative from the perspective of research, and will be used by senior managers, experts, analysts of Mellat bank and the banking systems of the country.

\section{Entrepreneurship Approaches}

Lumpkin and Dess, (1996) have described the entrepreneurial orientation, as an economic process and decision-making activity that resulted in a new input. Entrepreneurship orientation can be considered as an entrepreneurial process, which the managers use for entrepreneurial activity, while, entrepreneurship could be defined as a new entry. They have drawn 5 dimensions of entrepreneurship orientation, include: independence, innovation, risk taking, interaction, competitive invasion, which insist on all entrepreneurial processes.

Lee and Peterson, (2000) have defined the entrepreneurial orientation as the entrepreneurial process, which reveals that, how the entrepreneur will happen in terms of methods, operations, decision-making processes for new input to the market. They have stated that the firms that act independently and continue the test take risks and innovate and compete in their market, and have a strong entrepreneurship orientation; however, those who lack all of these have a weak entrepreneurship orientation.

Becherer and Maurer, (1997) have examined the relationship between entrepreneurial orientation, marketing trends and firm performance and indicated that entrepreneurial orientation is related to changes in profits.

Dess and et al ,(1997) have examined the nature of entrepreneurial strategy and its relationships with environmental strategy and high performance. The results of this study showed that entrepreneurship strategy has a strong relationship with firm performance, when combined with the right strategy and the same environment. The research of Covin and Slevin, (1991), also stated that the entrepreneurial orientation has a relation with performance among small firms in hostile environments.

Wikilund (1999), has examined the stability of the relationship between entrepreneurial orientation and firm 
performance. He has analyzed the data of Swedish firms and understood a positive correlation between entrepreneurship orientation and high performance. In addition, the research results showed that relationship has increased over time.

Antoncic model (2000), has considered the characteristics of organizational entrepreneurship (new business, new venture business, service and product innovation, process innovation, modernization, risk-taking and the hyperactive and aggressive competition) as well as the factors affecting it, (features of the organizations, departments and unit characteristics and environmental factors), in the study of organizational entrepreneurship.

Research states that the organization may show different shapes of these dimensions to comply the organizational strategy with the external environment (Kreiser 2002; Lumpkin and Dess, 1996)

In line with this, our research landscape looks at entrepreneurial approaches process, consisting of activism (hyperactive), innovation and risk taking, which may be the pioneers or resulted, depending on the internal or external content of the organization.

It seems, entrepreneurial approaches have an important influence on the development of the organization's strategy, and therefore, the investigator believes that the focus for Entrepreneurial Studies on the Mellat banks where very little attention has been devoted to it - on entrepreneurial approaches in explaining the strategy of development, in the bank, is very important.

In this study, we study the effect of five dimensions of entrepreneurial orientation, (independence, innovation, risk-taking, action-oriented, competitive aggression) on development strategy.

\section{Expression of Conceptual Model}

The research, based on previous research, such as Miller, has defined an entrepreneurial firm as a firm that is engaged in innovation of the product market and is made risky investments and is along with activities innovation, puts the rivals aside. He has used the aspect of activities, innovation and risk to evaluate entrepreneurial approach. These three dimensions had been taken by most prior research, to explain entrepreneurship (Lumpkin and Dess, 1996; Covin and Slevin, 1989; Lee Patterson, 2000 Kreiser, 2002 Tarabishky, 2005).

On the other hand, Kavyn and Slevin 1989 have stated according to Miller that, firms are entrepreneurs that will be an inno vative and proactive risk taker. In other studies, Kreiser has supported the three dimensions, including proactive innovation and risks and stated, these three dimensions can be different from each other in several mentioned occasions, by Lumpkin and Dess. Tarabishky has adopted the basic developed framework by Miller. They have focused on taking risks, innovation and action, to measure entrepreneurial strategic posture (ESP).

Table 1. A comparative study of entrepreneurship approaches

\begin{tabular}{|c|c|c|c|c|c|c|}
\hline Writer & Innovation & action & Risk & Independence & $\begin{array}{c}\text { Competitive } \\
\text { invasion }\end{array}$ & $\begin{array}{c}\text { Dynamic } \\
\text { competitive }\end{array}$ \\
\hline $\begin{array}{c}\text { Miller 1983 } \\
1989\end{array}$ & (-) & (-) & (-) & - & 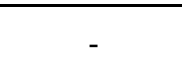 & $x_{2}$ \\
\hline Covin and Sle vin 1996 & (-) & (-) & (-) & - & - & - \\
\hline Lumpkin and Dess 1996 & (-) & ๑) & (-) & (-) & (-) & - \\
\hline Wikilund 1999 & (-) & (-) & (2) & - & - & - \\
\hline $\begin{array}{l}\text { 2002Lee and Peterson } \\
\text { Chrisser and et al } 2002\end{array}$ & (-) & (-) & (-) & (-) & - & (2) \\
\hline Marino. & (-) & (-) & (-) & - & - & - \\
\hline Masgham 2003 & (2) & (-) & (-) & - & - & - \\
\hline $\begin{array}{l}\text { Tarabishy and and et al } \\
2005\end{array}$ & (2) & (-) & (-) & - & - & - \\
\hline Moreno 2008 & (-) & (-) & (-) & - & - & - \\
\hline This research & (-) & (๑) & (-) & - & (-) & - \\
\hline
\end{tabular}

Also, when the relationship between aspects time comes, Miller (1993) and Kovin and Slevin (1989) have accepted entrepreneurship approaches as a one-dimensional structure. They have insisted that these three dimensions can be placed on a scale and on the other hand, Lumpkin and Dess (1996) and Christ and other (2002) have claimed that entrepreneurs' approaches dimensions can be different from each other. This research has adopted the attitude of Miller (1993) and Kovin and Slevin (1989). 


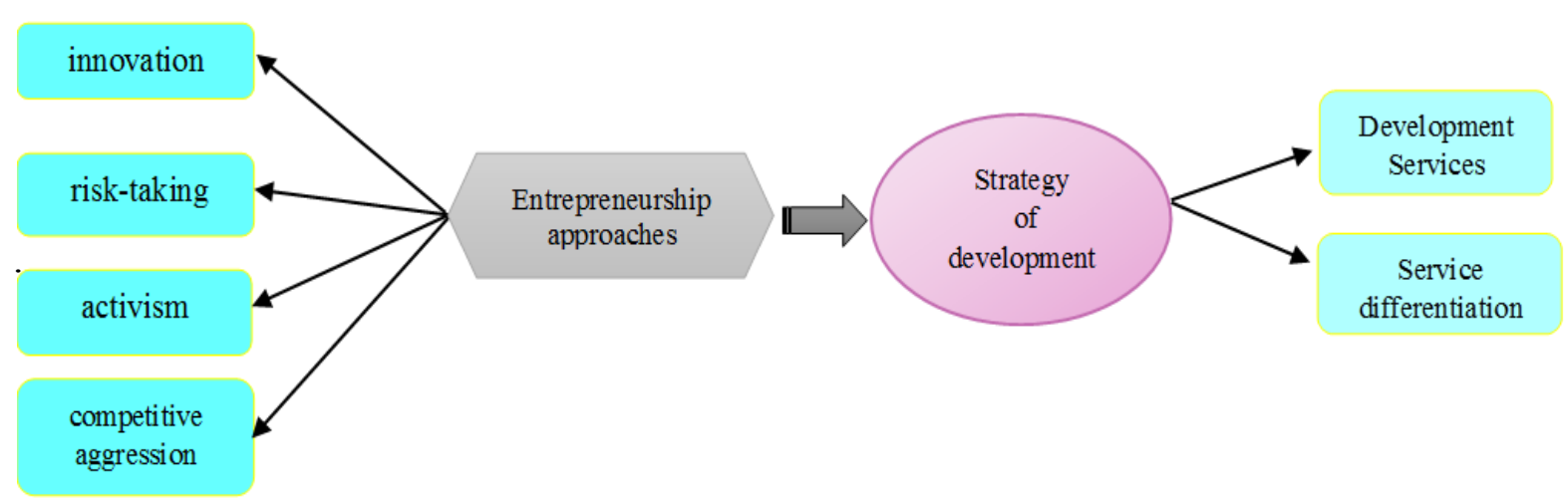

Figure 1. Conceptual model of research

\section{The Questions and Main Objective of the Research}

H1. There is a direct and significant relationship between entrepreneurial approaches and strategy of development.

H2. Competitive dynamics have a moderating effect on the relationship between entrepreneurship approaches and strategy of development.

In addition, the underlying aim of this research is to "investigate the effects of entrepreneurship approaches on development strategy".

\section{Research Methodology}

The research is applied in terms of objective, gathering information is descriptive-corrolation type, and gathering information was done by using survey methods. To identify aspects of entrepreneurship and de velopment strategy, the background of the research was studied. A questionnaire as designed with 62 closed questions with 5 -point Likert scale and 8 demographic questions. The statistical population of the research consisted of employees (managers and experts) of line and staff management headquarters and branches in Tehran that 1429 people were identified. The population is limited, therefore, in this study; finite population-sampling formula was used for sampling.

$$
n=\frac{1429 \times[1.96]^{2} \times 0.5 \times 0.5}{(0.05)^{2} \times(1429-1)+(1.96)^{2} \times 0.5 \times 0.5}=302.96 \cong 303
$$

$\mathrm{N}=$ the sample size, according to the formula, was calculated 303 number.

In this study, the number of samples, selected from each category, is calculated as follows :

$\mathrm{nn}=\mathrm{n} \mathrm{Nn} / \mathrm{N}$

Table 2. Statistical population

\begin{tabular}{cccccc}
\hline row & $\begin{array}{c}\text { The desired } \\
\text { class }\end{array}$ & All subjects & The questionnaire needed & Questionnaires sent & $\begin{array}{c}\text { Returned } \\
\text { questionnaires }\end{array}$ \\
\hline 1 & Management & 506 & $303 \times 506 / 1429=107.29$ & 140 & 70 \\
3 & professional & 741 & $303 \times 741 / 1429=157.11$ & 180 & 133 \\
2 & executive & 182 & $303 \times 182 / 1429=38.59$ & 100 & 58 \\
4 & Total & 1429 & 303 & 420 & 261 \\
\hline
\end{tabular}

However, for assurance of returning the questionnaire, more number of them was distributed. Questionnaires were distributed randomly-class so that 261 questionnaires were collected. In this study, to evaluate the validity of the questionnaire, professors and experts used content -face validity. In order to have the high reliability questionnaire, a pre-test was used. Thus, after designing the initial questionnaire, 30 questionnaires were distributed and collected trial that the level of its reliability was obtained 0.862 by using the Cronbach's alpha that indicates an acceptable credit.

\section{Data Analysis}

To analyze the data, after extracting factors from the research literature, for the extraction of entrepreneurship approaches and strategy of development, structural equation method and confirmatory factor analysis were used to test the research measurement models. In addition, to study the effect of moderator variables, Moderated Multiple Regression methods and correlation analysis of subgroups adjustment were used. 


\section{Research findings}

Among 261 respondents, $36 \%$ were male and 49 percent were female that $12.3 \%$ were ranged from $22-28$ years, 44.8 percent were from 29 to 35 years, 27.6 percent were 36 to 45 years and $0.4 \%$ were over 46 years. Respondents in terms of education, 10.3 percent had a high school diploma and associate degree, 46 percent had bachelor, 28 percent had master and 0.8 percent had PhDs. In terms of the service experienced, $11.9 \%$ had less than 5 years, $35.2 \%$ had between 5 and 10 years, $21.8 \%$ had between 10 and 15 years and $10.3 \%$ had between 15-20 years and 21 years and above work experience, and 14.6 percent did not ans wer the questions. In terms of the position, $21.8 \%$ of the respondents were managers, $54.8 \%$ were experts, 20.7 percent were executive staff, and 2.7 percent did not answer the question.

\section{Confirmatory Factor Anal ysis}

To establish causal relationships between independent variables and the dependent variables, the proposed model was analyzed by using structural equation and LISREL software. In the causal model, first, the initial model should be tested; therefore, different criteria of pattern fit should be applied. In this study, several indices were used, which its results are shown in Figure 3. As can be seen in the table, all the indices of fit confirm the framework (template). In general, if the value of GFI will be greater than or equal to 0.9 , indicates perfect fitting templates. On the other hand, the RMSEA must be less than 0.08 , and its confidence interval should not be very high, which in this model is about 0.071. In addition, the NFI, GFI and RFI, which are larger than 0.9 shows the satisfactory level of fitness model. Ratio of chi-square to the degrees of freedom as the most important indicator in determining the fitting, in this model is below 3 and equal to 2.30 , which is in the proper range.

Table 3. The fitting criteria for the final model

\begin{tabular}{|c|c|c|c|c|c|}
\hline & Indicators & The maximum allowable & Numbers & & result \\
\hline Chi-square ratio to the & $\begin{array}{r}\text { degree of } \\
\text { freedom }\end{array}$ & $\chi \quad / \mathrm{df}<3$ & 2.30 & A good fit & \\
\hline & RMSEA & $0.05<<0.08$ & 0.071 & A good fit & \\
\hline & GFI & Higher than 0.9 & 0.96 & A good fit & \\
\hline & AGFI & Higher than 0.9 & 0.91 & A good fit & \\
\hline & CFI & Higher than 0.9 & 0.98 & A good fit & \\
\hline & NFI & Higher than 0.9 & 0.97 & A good fit & \\
\hline & NNFI & Higher than 0.9 & 0.96 & A good fit & \\
\hline
\end{tabular}

After the pattern fit was logically confirmed by the data, significant components of the framework (template) and relationships between variables were evaluated. Figures 1 to 4 show LISREL parameter estimation in the examined model. These parameters all show the impact of each of these observer variables at the same time (rectangle) and latent (Oval), in the overall framework.

\section{The Main Research Hypotheses by Path Analysis}

One of the strongest and most appropriate analysis methods in behavioral sciences research is multivariate analysis. Because the nature of these issues is multivariate and cannot solve them with the two variables, method (each time only one independent variable with the dependent variable). Therefore, in this study, to confirm or refute the hypotheses, structural equation modeling and in particular, path analysis was used. Path analysis (structural model), is a technique that shows the relationships between research variables (independent, intermediate and dependent) simultaneously. The purpose of the path analysis is to identify causality (effect), between the conceptual model variables of the research.

Structural model shows the relationship between entrepreneurship approaches and development strategy. Structural model in the standard estimation mode, showed a positive effect (0.87) and significantly (15.28) between the approaches of entrepreneurship and development strategy. 


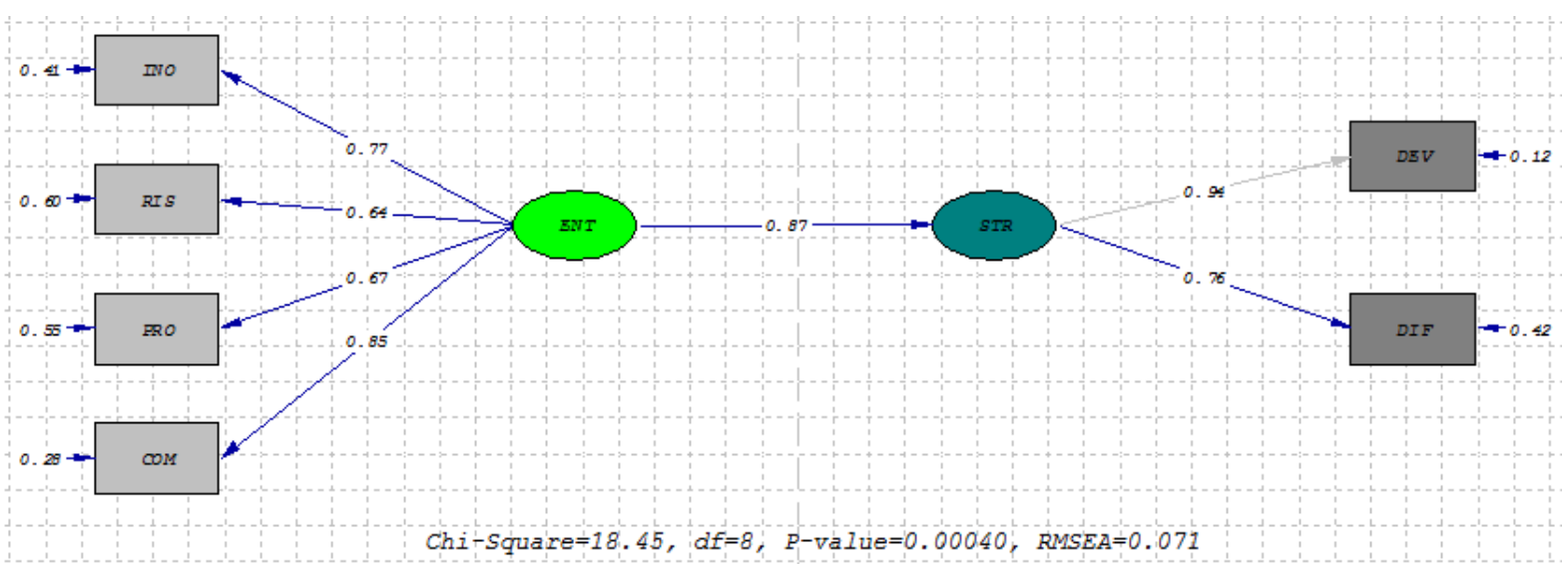

Figure 1. Structural Model in standard estimation mode

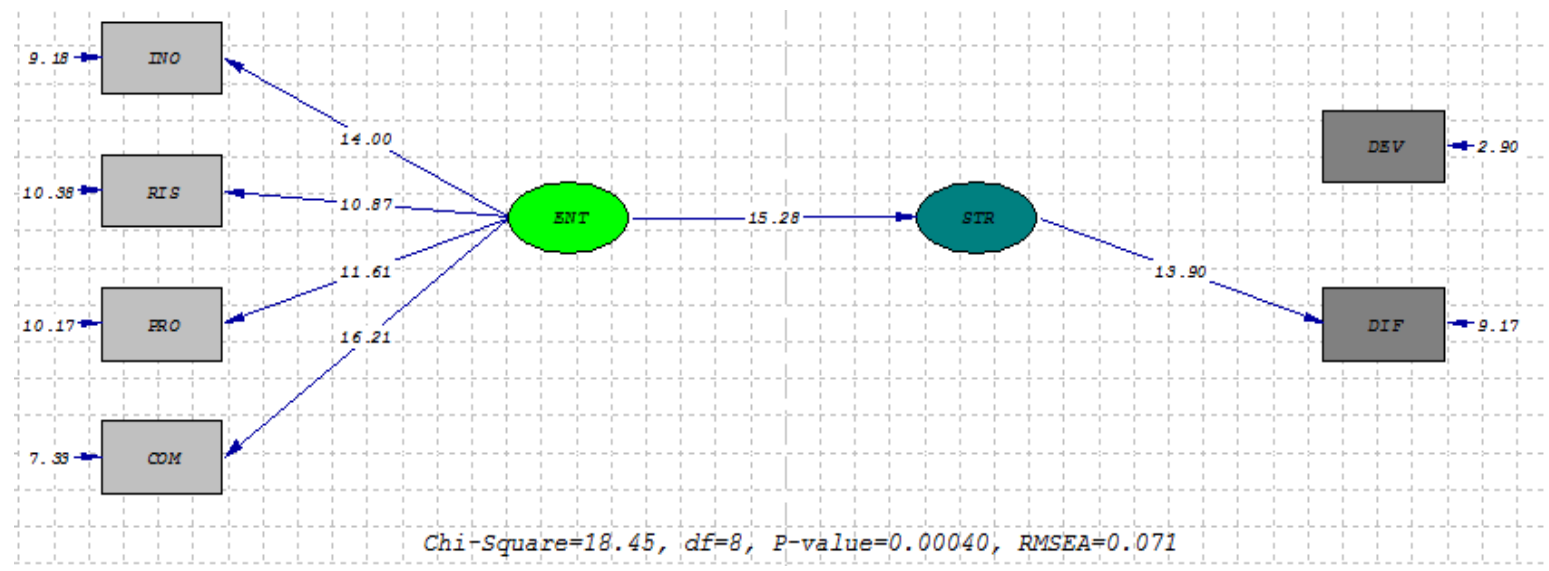

Figure 2. structural model in a significant factor mode

\section{Moderating Competitive Dynamics in the Relationship between Entrepreneurship and Development Strategy}

For testing and identification of moderator variables, there are three ways, that each of these methods has assumptions and specific requirements. In this study, to investigate the moderating dynamics of competition between entrepreneurship approaches and development strategy, the sub-group procedure is used. To this end, the moderator variable is divided into two high and low groups by using the average. In addition, each of them was run separately, after running, the impact factors were compared between entrepreneurship approaches variables and development strategy that in the case of a huge difference, a moderator command will be given.

Due to this that the dynamic variables can be considered as a category and class (low and high competitive dynamics ...). Therefore, the Subgroup analysis will be used for moderate form test of this variable on the relationship between the independent variable and the dependent variable in the model. In this way, in this method, first, we run the relevant structural equation model in all kinds of amounts and situations of mediator variables (low doses and high amounts) and we compare the results of these amounts and modes together, if the results of the models (especially regression coefficients) have significant differences, indicating a moderating effect on the considered relationship. 


\section{1) Competitive Dynamics}

\section{Small amounts (130 cases)}

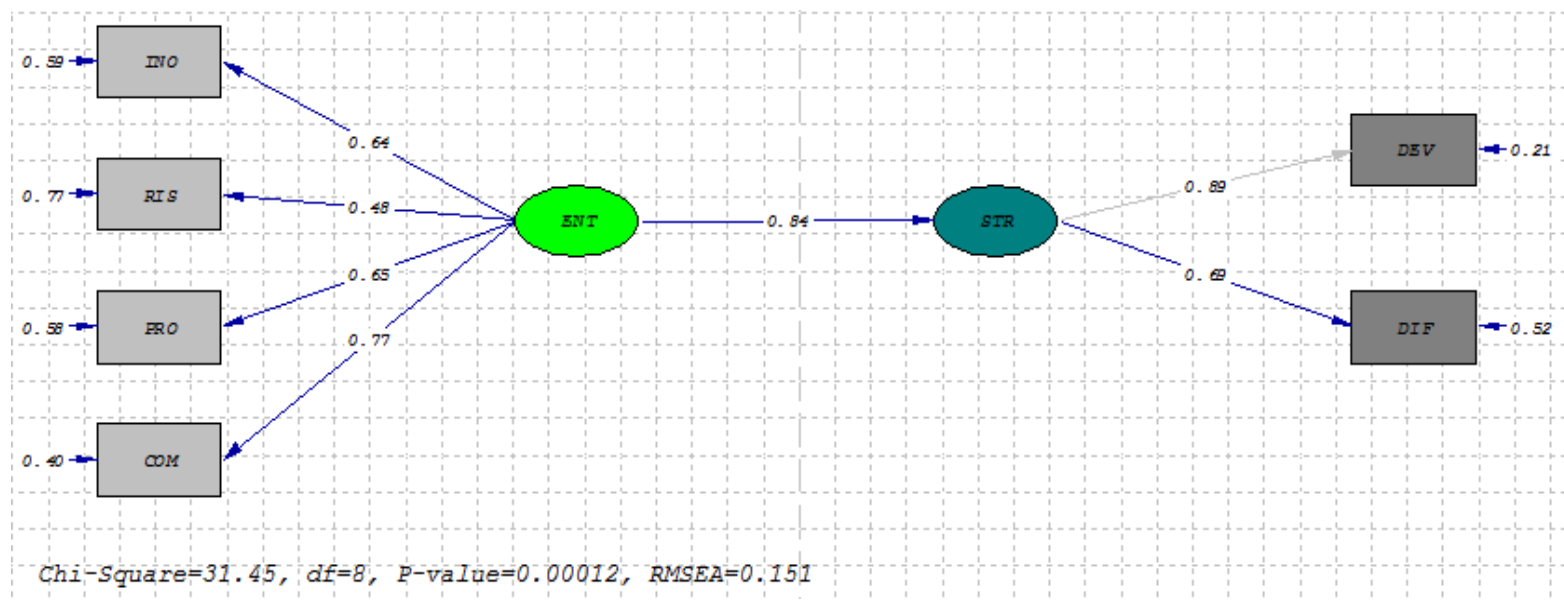

Figure 3. standard estimation model of small amounts moderating effect on competitive dynamic variables

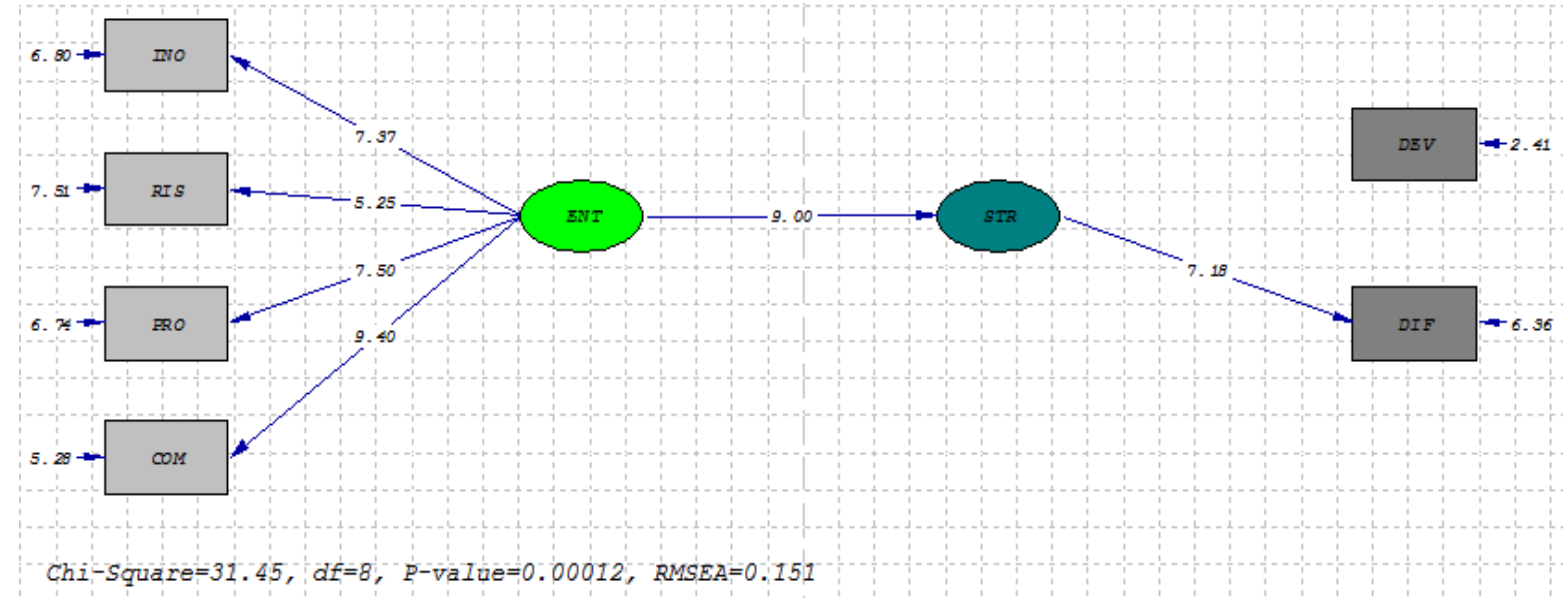

Figure 4. a significant moderating effect of small amounts on competitive dynamics variablelarge quantities (131 cases)

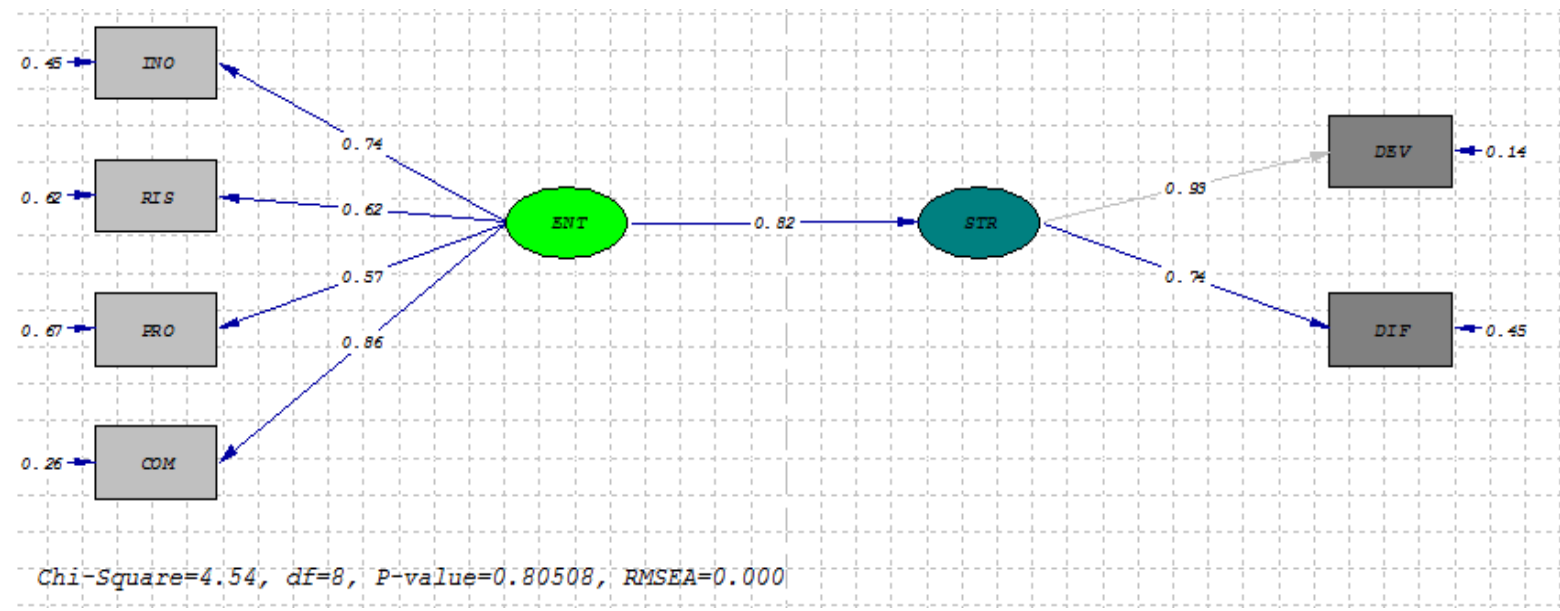

Figure 5. Standard regression models to estimate the effect of moderating high levels in competitive dynamic variable 


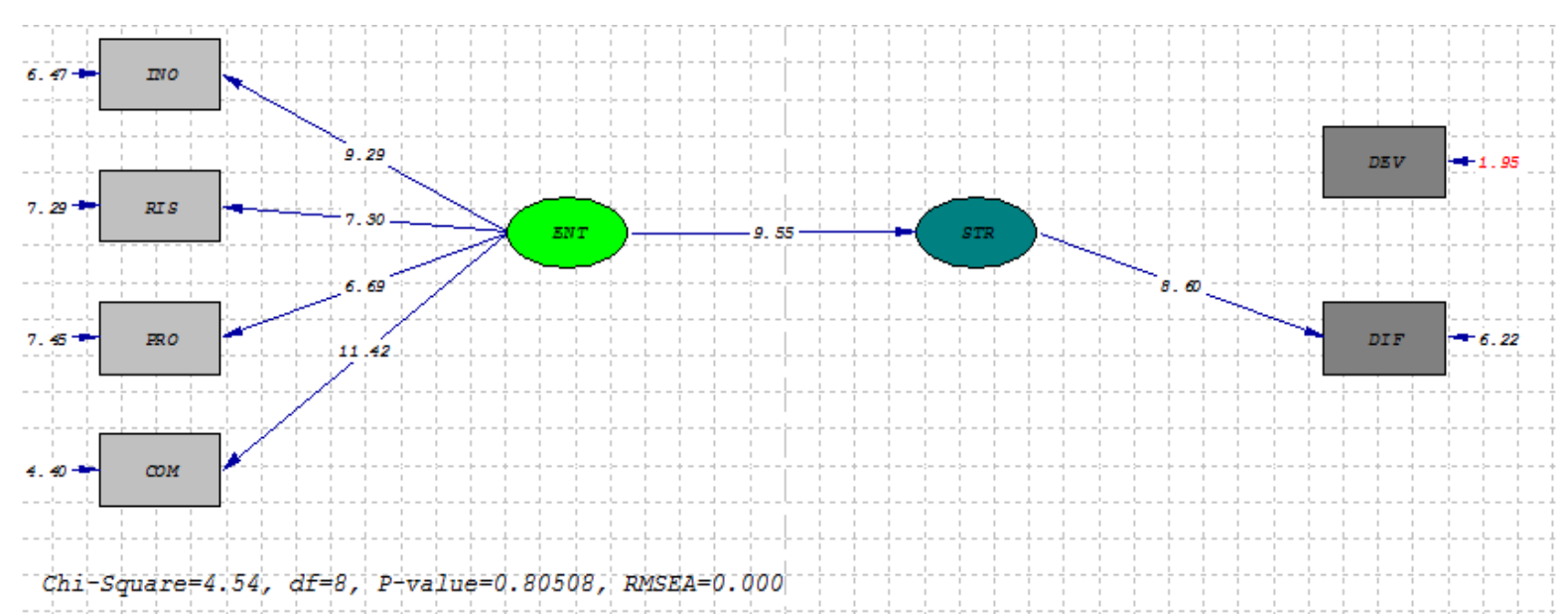

Figure 6. significant numbers of large amounts of moderating effect of competitive dynamics variable

Table 4. Comparison of low and high amounts moderating effect in competitive dynamics variable

Relations between model components
Low amounts of moderating variable
High amounts of moderating variable
The difference in the two models

Entrepreneurial approaches effect on development strategy

0.84 significant

0.82 significant

0.02 low

\section{Discussion and Conclusion}

Services industry is the largest and fastest growing part of the economy of a developed country, for example, in the US, the service industry uses about 76 percent of the work force and forms 57 GDP. Therefore, many previous studies have tried to identify the factors that effect on business performance by focusing on service quality, as a factor that satisfies customer needs and improve organizational performance (Asubonteng,1996; Lee and Ulgado, 1997; Ying, Cheng, 2006; Lee and Lim, 2009, Chen, Arttejo, 2008; Tang and et al,2009). However, it is difficult to find a study that has examined the impact of entrepreneurship approaches on the development strategy, despite the fact that the orientation of entrepreneurs is suggested as a mandatory feature of high-performance firms (Covin and Slevin, 1991; Lee and Peterson, 2000). There is a feature of experimental documentation regarding the impact of entrepreneurship approaches on the performance of the service business; therefore, the aim of this study is to investigate the effect of entrepreneurship approaches on the strategy of development as well as to evaluate competitive dynamics moderating in the relationship between entrepreneurship approaches and strategy of development. The present study has limitations and disadvantages as well. In this study, the proposed model was in the early stages of design, and should be used in future studies, in several organizations with different work activities, so that it is proven and its weaknesses will be determined. The study proposes a scale for all organizations, and variables such as size or industry have not been entered in it. Further studies can indigenous the proposed scale for every industry, in particular. This issue in particular, can be important for distinguishing between High-tech industries and Low-tech industries because the nature of used entrepreneurship is different in each of these industries and has different functions.

\section{References}

Ahmad, P. D. M. (2008). Entrepreneurs' definitions, theories, models, Tehran, Jajarmi.

Ahmad, P. D. M., \& Alaei, S. (2007). Entrepreneurship development strategy in part of the culture.

Ahmad, P. D. M., \& Moghimi, M. (2006). Principles of Entrepreneurship, Tehran: Faraandish.

Antoncic, B., \& Hisrich, R. D. (2001). Intrapreneurship: Construct Refinement and Cross-Cultural Validation. Journal of Business Venturing, 16, 495-527. https://doi.org/10.1016/S0883-9026(99)00054-3

Antoncic, B., \& Hisrich, R. D. (2004). Corporate Entrepreneurship Contingencies and Organizational Wealth Creation. Journal of Management Development, 23(6), 518-550. https://doi.org/10.1108/02621710410541114

Asubonteng, P., McCleary, K., \& Swan, J. (1996). SERVQUAL revisited: a critical review of service quality. JServ Mark, 10(6), 62-81. https://doi.org/10.1108/08876049610148602 
Becherer, R. C., \& Maurer, J. (1997). The moderating effect of environmental variables on the entrepreneurial and marketing orientation of entrepreneur-led firms. Entrepreneurship Theory Pract, 22(Fall), 71-94

Chen, J. V., \& Arttejo, B. A. (2008). Service quality and customer satisfaction measurement of mobile valueadded services: a conceptual view. Int $J$ Mobile Commer, 6(2), 165-176. https://doi.org/10.1504/IJMC.2008.016575

Choi, S., \& Mattila A. S. (2008). Perceived controllability and service expectations: influences on customer reactions following service failure. J Bus Res, 61(1), 24-30. https://doi.org/10.1016/j.jbusres.2006.05.006

Copyright $\odot 2016$ Strategic Management Society.

Covin, J. G., \& Miles, M. P. (1999). Corporate entrepreneurship and the pursuit of competitive advantage. Entrepreneurship Theory and Practice, 23(3), 47-63.

Covin, J. G., \& Slevin, D. P. (1991). A conceptual Model of Entrepreneurship as Firm Behaviour. Entrepreneurship Theory and Practice, 16(1), 7-25.

Covin, J. G., Green, K. M., \& Slevin, D. P. (2006). Strategic process effects on the entrepreneurial Orientation-Sales Growth Rate Relationship. Entrepreneurship Theory and Practice, 30(1), 57-81. https://doi.org/10.1111/j.1540-6520.2006.00110.x

Dess, G. G., \& Lumpkin, G. T. (2005). The Role of Entrepreneurial Orientation in Stimulating.

Dess, G. G., Ireland, R. D., Zahra, S. A., Floyd, S. W., Janney, J. J., \& Lane, P. J. (2003). Emerging dimensionality, and measurement. Management Science, 35, 942-444.

Dess, G. G., Lumpkin, G. T., \& Covin, J. G. (1997). Entrepreneurial Strategy Making and Firm Performance: Tests of Contingency and Configurational Models. Strategic Management Journal, 18(9), 677-695. https://doi.org/10.1002/(SICI)1097-0266(199710)18:9<677::AID-SMJ905>3.0.CO;2-Q

Dess, G. G., Lumpkin, G. T., \& Eisner, A. B. (2007). Strategic Management: Text and Cases, 3rdEd. New York, NY: McGraw-Hill/Irwin.

Divandari, A., \& Hassanpour, A. (2007). Examine how to strengthen the entrepreneurial attitude of bankers in the nation. The first National Conference on Entrepreneurship, Tehran, Feb 25-26.

Farhangi, A. A., \& Safarzadeh, H. (2007). entrepreneurs (concepts, theories, models and applications, Tehran: Institute of Labor and Social Security.

Gasse, Y. (1982). Elaborations on the psychology of the entrepreneur. In C. A. Kent, D. L. Sexton, \& K. H.

Gholipour, R. et al. (2008). Analysis of the Relationship and social capital impact on organizational Entrepreneurship, management culture, sixth year, Issue seventeenth, S111-129.

Guth, W. D., \& Ginsberg, A. (1990). Guest Editors' Introduction: Corporate Entrepreneurship. Strategic Management Journal, 11, 5-15.

Hadizadeh, A., \& Rahimi, P. A. F. (2004). Organizational entrepreneurship, Tehran: Janan.

Kermanshah, A., \& Abdi, M. (2006). The strategy in the banking industry, International Management Conference.

khanka, S. (2003). Entrepreneurial Development, New Delhi: Chandan Company, Ltd.

Korunka, C., Frank, H., Lueger, M., \& Mugler, J. (2003). The entrepreneurial personality in the context of resources, environment, and the startup process-Aconfigurational approach. Entrepreneurship Theory and Practice, 28(1), 23-42. https://doi.org/10.1111/1540-8520.00030

Kreiser, P. M., Marino, L. D., \& Weaver, K. M. (2002) Assessing the psychometric properties of the entrepreneurial orientations scale: a multi-country analysis. Entrepreneurship Theory Pract, 26(Spring), 71-94.

Lee, M., \& Ulgado, F. (1997). Consumer evaluations of fast food services: a cross-natural comparison. J Serv Mark, 11(1),39-52. https://doi.org/10.1108/08876049710158358

Lee, S. M., \& Lim, S. (2009). Entrepreneurial orientation and the performance of service business. Service Business, 3, 1-13. https://doi.org/10.1007/s11628-008-0051-5

Lee, S., \& Peterson, S. (2000). Culture, entrepreneurial orientation, and global competitiveness. $J$ World Bus, 35(4), 401-416. https://doi.org/10.1016/S1090-9516(00)00045-6 
Li, Y. H., Huang, J. W., \& Tsai, M. T. (2009). Entrepreneurial orientation and firm performance: The role of knowledge, creation process. Industrial Marketing Management, 38, 440-449. https://doi.org/10.1016/j.indmarman.2008.02.004

Lumpkin, G. T., \& Dess, G. G. (1996). Clarifying the entrepreneurial orientation construct and linking it to performance. Acad Manag Rev, 21(1), 135-172.

Lumpkin, G. T., \& Dess, G. G. (1996). Clarifying the entrepreneurial orientation construct and linking it to performance. Academy of Management Review, 21 (1), 135-172.

Lumpkin, G. T., \& Dess, G. G. (2001). Linking Two Dimensions of Entrepreneurial Orientation To Firm Performance: The Moderating Role Of Environment And Industry Life Cycle. Journal of Business Venturing, 16, 429-451. https://doi.org/10.1016/S0883-9026(00)00048-3

Lynch, R. (2006). Corporate strategy.

Marino, L., Strandholm, K., Steensma, H. K., \& Weaver, K. M. (2002) The moderating effect of national culture on the relationship between entrepreneurial orientation and strategic alliance portfolio extensiveness. Entrepreneurship Theory Pract, 26(Summer), 145-160.

McGrath, R. G., \& MacMillan, I. (2000). The.boston,Ma;Harvard Business Press.

Messeghem, K. (2003). Strategic entrepreneurship and managerial activities in SMEs. Int Small Bus J, 21(2), 197-212. https://doi.org/10.1177/0266242603021002004

Miller, D. (1983). The correlates of entrepreneurship in three types of firms. Management Science, 29, 770-791. https://doi.org/10.1287/mnsc.29.7.770

Miller, D., \& Friesen, P. H. (1978). Archetypes of strategy formulation. Management Science, 24, 921-933. https://doi.org/10.1287/mnsc.24.9.921

Miller, D., \& Friesen, P. H. (1982). Innovation in conservative and entrepreneurial firms: Two models of strategic momentum. Strategic Management Journal, 3, 1-25. https://doi.org/10.1002/smj.4250030102

Miller, D., \& Friesen, P. H. (1983). Strategy-making and environment: The third link. Strategic Management Journal, 4, 221-235. https://doi.org/10.1002/smj.4250040304

Mintzberg, H., \& Waters, J. A. (1982). Tracking strategy in an entrepreneurial firm. Academy of Management Journal, 25(3), 465-490. https://doi.org/10.2307/256075

Moghaddam, K. et al (2016). Strategic alliances of enterpreneurilal ferms: of value enhancing then value destroying. Strategic Entrepreneurship Journal Strat. Entrepreneurship J., 10, 153-168. https://doi.org/10.1002/sej.1221

Mohammadkazemi, R., Rasekh, N., \& Navid, M. (2016). The Effect of Entrepreneurial Competencies on Innovation: A Case Study of Professional Sport Clubs. International Business Research, 9(11). https://doi.org/10.5539/ibr.v9n11p57

Moreno, A. M., \& Casillas, J. C. (2008). Entrepreneurial orientation and growth of SMEs: A causal model. Entreprenership Theory and Practice, 32(3), 507-528. https://doi.org/10.1111/j.1540-6520.2008.00238.x

Pardakhtchi \& Shafi'zadeh (2005). Introduction to entrepreneurship organizations.

Porter, M. (1980). Competitive Strategy.

Salazar. (2004). Introduction to Entrepreneurship translations spokesman Siamak Iranian National Productivity Seal.

Schumpeter, J. A. (1934). The Theory of Economic Development. Cambridge, MA.

Shane, S., \& Venkataraman, S. (2000). The promise of entrepreneurship as a field of research. Academy of Management Review, 25, 217-226. https://doi.org/10.5465/amr.2000.2791611

Stevenson, H. H., \& Jarillo, J. C. (1990). A paradigm of entrepreneurship: Entrepreneurial management. Strategic Management Journal, 11, 17-27.

Tang, T., Kreiser, P. M., Marino, M., Dickson, P., \& Weaver, K. M. (2009). A hierarchical perspective of the dimensions of entrepreneurial orientation. Int Entrep Manag, 5, 181-201. https://doi.org/10.1007/s11365-008-0097-9

Tarabishy, A., Solomon, G., Fernald, L., \& Saghkin, M. (2005). The entrepreneurial leader's impact on the organization's performance in dynamic markets. $J$ Priv Equity, 8(4), 20-29. 
https://doi.org/10.3905/jpe.2005.580519

Vesper (Eds.) (1984). Encyclopedia of entrepreneurship (pp. 209-223). Englewood Cliffs, NJ: Prentice.

Wickham, P. A. (2000). 'Strategic Entrepreneurship' A decision making approach to new venture creation and management, Prentice Hall.

Wikilund, J. (1999). The sustainability of the entrepreneurial orientation-performance relationship. Entrepreneurship Theory Pract, 24(Fall), 37-48.

Ying, J., \& Cheng, L. W. (2006). The impact of affecting on service quality and satisfaction: the moderation ofservice contexts. J Serv Mark, 20(4), 211-218. https://doi.org/10.1108/08876040610674562

Zohari, M. (2012). Identification effect entrepreneurial approaches, The Banking Industry Development Strategy. A Thesis Presented for the Degree of Master.with Supervisor Dr. Sepehri, M.

\section{Copyrights}

Copyright for this article is retained by the author(s), with first publication rights granted to the journal.

This is an open-access article distributed under the terms and conditions of the Creative Commons Attribution license (http://creativecommons.org/licenses/by/4.0/). 